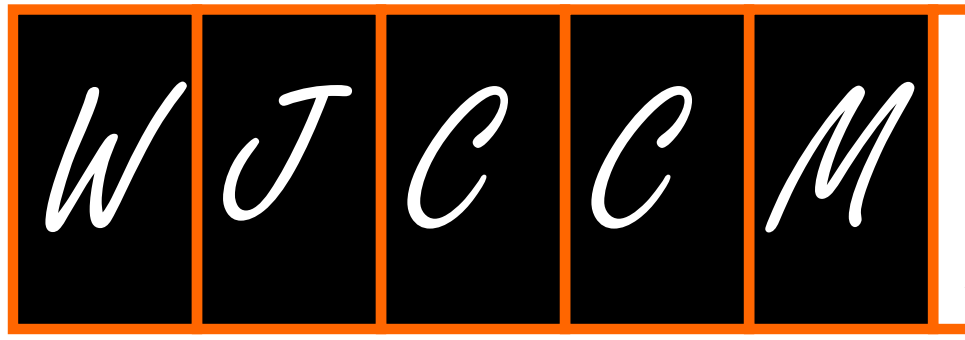

Submit a Manuscript: https:/ / www.f6publishing.com

\section{World Journal of Critical Care Medicine}

World J Crit Care Medl 2019 September 11; 8(5): 59-71

\title{
Diagnosis and treatment of acute pulmonary inflammation in critically ill patients: The role of inflammatory biomarkers
}

\author{
Sarah Chalmers, Ali Khawaja, Patrick M Wieruszewski, Ognjen Gajic, Yewande Odeyemi
}

\section{ORCID number: Sarah Chalmers (0000-0001-6565-9023); Ali Khawaja (0000-0002-1595-9316); Patrick M Wieruszewski \\ (0000-0002-5871-5186); Ognjen Gajic (0000-0003-4218-0890); Yewande Odeyemi (0000-0002-4446-198X).}

Author contributions: Chalmers $S$, Khawaja A, Wieruszewski PM, Ognjen G, and Odeyemi $Y$, contributed to writing of the manuscript, provided intellectual contributions

\section{Conflict-of-interest statement: Authors declare no conflict of interests for this article.}

\section{Open-Access:This article is an} open-access article which was selected by an in-house editor and fully peer-reviewed by external reviewers. It is distributed in accordance with the Creative Commons Attribution Non Commercial (CC BY-NC 4.0) license, which permits others to distribute, remix, adapt, build upon this work non-commercially, and license their derivative works on different terms, provided the original work is properly cited and the use is non-commercial. See: http:/ / creativecommons.org/licen ses/by-nc/4.0/

\section{Manuscript source: Invited manuscript}

\section{Received: May 2, 2019}

Peer-review started: May 5, 2019

First decision: June 6, 2019

Revised: July 2, 2019

Accepted: August 6, 2019

Article in press: August 7, 2019
Sarah Chalmers, Ali Khawaja, Patrick M Wieruszewski, Ognjen Gajic, Yewande Odeyemi, Multidisciplinary Epidemiology and Translational Research in Intensive Care Group, Mayo Clinic, Rochester, MN 55905, United States

Sarah Chalmers, Ali Khawaja, Ognjen Gajic, Yewande Odeyemi, Division of Pulmonary and Critical Care Medicine, Mayo Clinic, Rochester, MN 55905, United States

Patrick M Wieruszewski, Department of Pharmacy, Mayo Clinic, Rochester, MN 55905, United States

Corresponding author: Sarah Chalmers, MD, Fellow, Division of Pulmonary and Critical Care Medicine, Mayo Clinic, 200 First Street SW, Rochester, MN 55905, United States.

chalmers.sarah@mayo.edu

Telephone: +1-507-2663958

Fax: $+1-507-2664372$

\section{Abstract}

Pneumonia and acute respiratory distress syndrome are common and important causes of respiratory failure in the intensive care unit with a significant impact on morbidity, mortality and health care utilization despite early antimicrobial therapy and lung protective mechanical ventilation. Both clinical entities are characterized by acute pulmonary inflammation in response to direct or indirect lung injury. Adjunct anti-inflammatory treatment with corticosteroids is increasingly used, although the evidence for benefit is limited. The treatment decisions are based on radiographic, clinical and physiological variables without regards to inflammatory state. Current evidence suggests a role of biomarkers for the assessment of severity, and distinguishing sub-phenotypes (hyperinflammatory versus hypo-inflammatory) with important prognostic and therapeutic implications. Although many inflammatory biomarkers have been studied the most common and of interest are C-reactive protein, procalcitonin, and pro-inflammatory cytokines including interleukin 6 . While extensively studied as prognostic tools (prognostic enrichment), limited data are available for the role of biomarkers in determining appropriate initiation, timing and dosing of adjunct anti-inflammatory treatment (predictive enrichment)

Key words: Acute pulmonary inflammation; Inflammatory biomarkers; Acute respiratory distress syndrome; Pneumonia; Critical illness; Diagnosis; Treatment

CThe Author(s) 2019. Published by Baishideng Publishing Group Inc. All rights reserved. 
Published online: September 11, 2019

P-Reviewer: Aurilio C, Yeh YC, Inchauspe AA

S-Editor: Dou Y

L-Editor: A

E-Editor: Liu MY

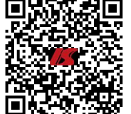

Core tip: Community acquired pneumonia and acute respiratory distress syndrome are common and important causes of respiratory failure in the intensive care unit. Both clinical entities are characterized by acute pulmonary inflammation in response to direct or indirect lung injury and current evidence suggests a role of biomarkers for the assessment of severity, and distinguishing sub-phenotypes (hyper-inflammatory versus hypo-inflammatory) with important prognostic and therapeutic implications.

Citation: Chalmers S, Khawaja A, Wieruszewski PM, Gajic O, Odeyemi Y. Diagnosis and treatment of acute pulmonary inflammation in critically ill patients: The role of inflammatory biomarkers. World J Crit Care Medl 2019; 8(5): 59-71

URL: https://www.wjgnet.com/2220-3141/full/v8/i5/59.htm

DOI: https://dx.doi.org/10.5492/wjccm.v8.i5.59

\section{INTRODUCTION}

Inflammation is a natural body response to infectious and non-infectious insults resulting in a complex variety of mechanisms that eventually lead to tissue repair. Inflammatory response in the lungs is most commonly due to infections, and exposure to toxins, allergens and irritants. Normal inflammation is intended to be protective but when excessive and/or prolonged can have deleterious effects associated with worse outcome ${ }^{[1]}$. The most common acute pulmonary inflammatory conditions in the intensive care unit (ICU) are pneumonia, community or health care acquired, and acute respiratory distress syndrome (ARDS), a complication of other acute illnesses.

Community acquired pneumonia (CAP) is a leading infectious cause of hospitalizations worldwide accounting for over 1 million inpatient hospitalizations annually in the United States ${ }^{[2,3]}$. Limited data suggests about $20 \%$ of adults hospitalized for pneumonia required an ICU admission which was directly associated with a $50 \%$ increase in length of hospital stay ${ }^{[4]}$. Although less common than pneumonia, ARDS accounts for approximately $10.4 \%$ of ICU admissions worldwide with an associated $40 \%$ mortality rate depending on severity ${ }^{[5]}$. It usually occurs as a sequela of other acute illnesses including pneumonia and non-pulmonary sepsis. Other risk factors are aspiration pneumonia, trauma and transfusion of blood products.

Together, both conditions have a significant impact on morbidity and mortality in the ICU with an associated increase in overall health care utilization despite early antimicrobial therapy and lung protective mechanical ventilation ${ }^{[5,6]}$. Acute and sometimes exaggerated inflammatory response is a common and important feature in both clinical entities with important prognostic implications and reflective of an ineffective regulatory mechanism to limit inflammation-induced damage $\mathrm{e}^{[7,8]}$. Adjunct anti-inflammatory treatment (i.e., corticosteroids) is often used, however the treatment decisions are based on severity of illness without regards to inflammatory state.

Several inflammatory biomarkers have been identified and implicated in the pathophysiology of inflammatory response in pneumonia and ARDS. More recently, several studies have assessed the role of biomarkers as key evaluation and management tools specifically aiding diagnoses, assessing severity, prognostication and informing therapeutic strategies.

This review focuses on biomarkers and their potential role in the evaluation and management of acute inflammation in CAP and ARDS in critically ill patients.

\section{PATHOPHYSIOLOGY OF ACUTE PULMONARY INFLAMMATION}

Acute pulmonary inflammation involves both the innate and adaptive immune responses. When a pathogen is encountered, the airway epithelium acts as the first line of defense mechanism. It is well equipped to release several enzymes including defensins, mucins and lyzozymes along with reactive oxygen species (ROS), nitric oxide, platelet activating factor and cytokines to attract inflammatory cells. In addition, plasma cells secrete IgA which creates an overlying epithelial protective barrier preventing microbial adherence, and surfactant proteins A and D in the alveoli 
sacs stick to surface bacterial molecules to facilitate opsonization ${ }^{[1,9]}$. If a pathogen is able to overcome the epithelium's defenses, it encounters a group of inflammatory cells particularly macrophages, dendritic cells and lymphocytes, residing in the airways and throughout the lung parenchyma and interstitium. Dendritic cells are antigen presenting cells which not only stimulate the naïve $\mathrm{T}$ cell lymphocytes but also potentiate macrophages and assist in phagocytosis. They do so with the help of toll like receptors on their surfaces also referred to as pattern-recognition receptors which identify pathogen associated molecular patterns on pathogens' surfaces ${ }^{[1,10]}$. Stimulated naïve T cells activate either a T helper 1 (Th 1 ) and Th2 response which results in both cell-mediated and humoral mediated immune responses against the invading organism. This culminates in further stimulation of macrophages and $\mathrm{T}$ lymphocytes resulting in the release of a variety of chemokines and cytokines based on the type of invading pathogen, including interferon gamma, tumor necrosis factor (TNF)-a, interleukin (IL)-1, IL-4, IL-5, IL-6, IL-8, IL-9, IL-12 and IL-13. Simultaneously, the lung insult activates the capillary endothelial cells which in addition to contributing towards chemokine release, upregulate the surface adhesion molecules facilitating the attachment and migration of inflammatory cells to the site of insult ${ }^{[1]}$. In acute inflammation, neutrophils are the primary cells to respond to the cytokine release; IL-8 being the primary neutrophil chemotactic cytokine. Neutrophils kill the phagocytosed pathogens with ROS, antimicrobial proteins and elastase. If the lung insult has been successfully controlled, a rise in anti-inflammatory cytokines particularly IL-10, TGF- $\beta$ and IL-1Ra is expected. These assist in down regulating the defense system and facilitate apoptosis of the inflammatory cells by macrophages ${ }^{[11]}$. However, in cases of overwhelming infection, the anti-inflammatory mechanisms are unable to control the underlying inflammation resulting in continuous lung injury.

In early ARDS, increased capillary permeability is the hallmark outcome of the inflammatory process resulting from direct or indirect lung injury with disruption of the capillary-alveolar interface. This leads to leakage of protein-rich fluid from the capillary into the alveoli resulting in diffuse alveolar injury triggering an overwhelming release of pro-inflammatory cytokines mainly TNF, IL-1 and IL-6 and creating an imbalance between pro-inflammatory and anti-inflammatory cytokines. This initiates the inflammation cascade and recruits' neutrophils which again play a crucial role in causing inflammation by releasing ROS and proteases. It has been noted that patients with ARDS, have transcription abnormalities involving NF-kappa $\mathrm{B}$ which is required for transcription of genes responsible for pro-inflammatory mediators. Other substances such as endothelin-1, angiotensin-2 and phospholipase A2 have also been found to worsen vascular permeability and underlying inflammation causing increased lung injury ${ }^{[12-15]}$. A hyper- inflammatory sub phenotype in ARDS has been recently identified and associated with worse outcomes compared to a hypo-inflammatory sub phenotype ${ }^{[8]}$.

\section{DIAGNOSIS, EVALUATION, AND MANAGEMENT OF CAP AND ARDS-EVIDENCE ON INFLAMMATORY BIOMARKERS}

Early identification and assessment of severity are essential for institution of timely antibiotic therapy and appropriate supportive care in CAP and ARDS. As current diagnostic, evaluation, and management strategies are based on radiographic, clinical and physiological variables only, the use of biomarkers in these conditions has been proposed and extensively evaluated.

A biomarker is "a defined characteristic that is measureable and an indicator of normal biological processes, pathogenic processes, or responses to an exposure or intervention" [16]. The quintessential biomarker that can aid early identification, prognostication, as well as guide and monitor response to treatment in critically ill patients with acute pulmonary inflammation has been long sought-after. Several other fields have successfully identified biomarkers with therapeutic implications and improvement in outcomes. The identification of the programed cell death ligand-1 (PD-L1) and its role in several malignancies, led to the development of PD-L1 inhibitors which have revolutionized the treatment of several types of cancer. Asthma is another example of a heterogeneous disease that was revolutionized by the identification of various phenotypes and the associated biomarker(s) leading to treatments such as anti-IL-5 inhibitors. Recent evidence and ongoing efforts suggests a potential for similar success in CAP and ARDS with the recent identification of hyperinflammatory phenotypes with important prognostic and therapeutic implications ${ }^{[8,17]}$. The biomarkers that have been most extensively studied in CAP include C-reactive protein (CRP) and procalcitonin (PCT) and in ARDS, cytokines which will henceforth be reviewed. 
CRP

CRP was first discovered in 1930. Scientists William S Tillet and Thomas Francis Jr, discovered a novel antigen on the surface of pneumococcal bacteria that was present in the initial stages of infection and resolved as the patient improved ${ }^{[18]}$. Several years later, it was discovered that this "antigen" was a protein involved in acute systemic inflammation, CRP.

CRP is an acute phase protein predominately synthesized in hepatocytes in response to IL-6. As part of the innate immune response, it binds to microorganisms and stimulates phagocytosis and activation of the classical complement pathway ${ }^{[19]}$. It is detectable in serum within 6-10 h of inflammation initiation and has a half-life of approximately $25 \mathrm{~h}$ accounting for its rapid disappearance as inflammation subsides ${ }^{[20]}$. It is a non-specific acute phase reactant and has been shown to be elevated in various types of inflammation including infection regardless of pathogen type, malignancy, autoimmune disorders, and systemic inflammatory response syndrome (SIRS) PCT was more recentlyoccurring without active infection ${ }^{[21]}$. Current literature supports its use in diagnosis of pneumonia, assessment of severity of illness, prognostication, and assessment of clinical stability though the literature can be difficult to interpret due to the heterogeneous populations studied and the wide array of cut off levels suggested ${ }^{[22]}$ (Table 1). Given its non-specific but direct correlation with the innate immune system, its rapid turn-around time, low cost, and wide availability, it could be used as a biomarker to help identify and guide treatment in patients with hyper-inflammatory phenotypes of CAP. Further studies are needed to help define the natural history of CRP in hyper-inflammatory CAP phenotypes.

\section{PCT}

PCT was more recently discovered. It is a 116 amino acid peptide precursor to calcitonin and is encoded by the CALC-1 gene. In non-infectious states, it is produced in the $C$ cells of the thyroid gland. In the presence of infection, and in particular, systemic bacterial infection, CALC-1 gene expression is induced in nonneuroendocrine cells throughout the body and transcription and translation of PCT occurs. In addition, release of interferon stimulated by viral infection has been shown to down-regulate the production of PCT. It is detec in serum within $4 \mathrm{~h}$ of onset of infection and peaks within $12-48 \mathrm{~h}^{[23-25]}$.

While it is often used as a marker of systemic bacterial infection, it may not be elevated in isolated infections such as abscesses or empyema. Similar to CRP, it can be elevated in SIRS without infection. Accuracy in patients with renal dysfunction has been brought into questions as levels can be falsely elevated due at least in part to impaired clearance though higher cut off levels have been proposed in this population ${ }^{[26]}$. Similar to CRP, current literature supports its use in diagnosis, assessment of severity of illness, prognostication, and assessment of clinical stability in patients with CAP. In addition, it has been shown to be effective in identifying bacterial pathogens as the source of infection and in de-escalation of antibiotic therapy ${ }^{[2]}$. (Table 1)

\section{$C R P$ and $P C T$ in CAP}

CRP and PCT have been shown to aid in diagnosis in CAP particularly in comparison to clinical signs and symptoms alone and in patients with co-morbid conditions that contribute to clinical ambiguity, such as chronic obstructive pulmonary disease and acute heart failure. ${ }^{[25,27]}$. However, time from symptom onset to initial healthcare presentation may impact initial levels of CRP and PCT. A study looked at 541 patients who presented to the emergency department with CAP and were differentiated into early presenters ( $<3 \mathrm{~d}$ since onset of symptoms) and late presenters $(>3 \mathrm{~d})$. Results showed that CRP and PCT were lower in patients who were early presenters suggesting that time to presentation may affect the interpretation of these biomarkers ${ }^{[28]}$.

Both CRP and PCT have demonstrated moderate positive correlation with severity of disease assessed by CURB-65 with a receiver operating characteristic curves of 0.61 and 0.72 respectively ${ }^{[29]}$.

Evidence of CRP and PCT in prognostication of CAP is variable. One recent crosssectional study of 93 hospitalized adult patients with CAP showed a statistically significant association with mortality in patients with PCT $>0.5 \mathrm{ng} / \mathrm{mL}^{[29]}$. Another study assessed prognostication ability of PCT alone and in conjunction with CURB-65 compared with CRP and leukocytes, and demonstrated a better prediction of mortality of PCT alone which was increased in combination with CURB-65 ${ }^{[30]}$. Yet another study showed that elevated PCT was able to predict an increase in adverse events but not mortality ${ }^{[30,31]}$. The correlation of CRP with prognosis in CAP has varied with some studies demonstrating prognostic value of initial CRP while other studies demonstrate the prognostic ability of CRP trend but not initial measurement ${ }^{[32-34]}$. A 


\begin{tabular}{ll}
\hline Role & Biomarker \\
\hline Diagnosis & CRP, PCT, Ang 1, Ang 2 \\
Severity of illness & CRP, PCT, Ang 1, Ang 2, Pro-ADM, Pro-ANP, Pro-VNP, SP-D, YKL-40, CCL 18, Endocan, NETs, FGF21, \\
Clinical instability & CRP, PCT, NETs, FGF21 \\
De-escalation antibiotic & PCT \\
Prognostication & CRP, PCT, Ang 1, Ang 2, Pro-ADM, Pro-ANP, Pro-VNP, SP-D, YKL-40, CCL 18, NETs, FGF21 \\
\hline
\end{tabular}

CRP: C-reactive protein; PCT: Procalcitonin; Ang 1: Barrier stabilizing angiopoietin 1; Ang 2: Barrier stabilizing angiopoietin 2; pro-ADM: Proadrenomedullin; pro-ANP: Pro-atrial natriuretic peptide; pro-VNP: pro-vasopressin; SP-D: Surfactant protein-D; YKL-40: Human cartilage glycoprotein YKL-40; CCL18: Chemokine ligand 18; NET: Neutrophil extracellular trap; FGF21: Fibroblast growth factor 21.

recent prospective observational study evaluated the natural history of CRP in hospitalized patients with CAP, and showed that CRP at day 3 and 5 as opposed to initial CRP measurement, predicted mortality ${ }^{[32]}$. One study even demonstrated that lack of CRP decline regardless of initial value was predictive of 30-day mortality ${ }^{[35]}$. A recent study compared independent prognostication for PCT, CRP, and three pneumonia severity scores (Pneumonia Severity Index, CURB-65, IDSA/ATS defined severe $\mathrm{CAP}$ ) and three mortality prediction tools [Acute Physiology Chronic Health Evaluation II, Sequential Organ Failure Assessment (SOFA), and quick SOFA]. AUC for each clinical prediction tool was similar to PCT and slightly higher than CRP (AUC range of pneumonia severity scores 0.77-0.87; AUC range of mortality scores 0.81-0.85; AUC for PCT 0.83; AUC for CRP 0.77) ${ }^{[36]}$. With justification from prior studies demonstrating improved predictability with combination clinical predictor tools as well as CRP and/or PCT levels, a study proposed a new clinical decision tool for in hospital mortality in patients with severe CAP that incorporated previous prediction tool elements in conjunction with CRP ${ }^{[37]}$.

In a large multi-center randomized control trial, evaluating steroid treatment in hospitalized patients with severe community-acquired pneumonia (CAP), an inclusion criterion of CRP $>150 \mathrm{mg} / \mathrm{L}$ on admission was utilized. The results of this study demonstrate a reduction in treatment failure in the steroid group compared with placebo and indicates that, CRP may be a useful tool to help identify the population that may benefit from adjunctive corticosteroid therapy ${ }^{[17]}$. In addition, CRP may have the potential to help guide duration of treatment as steroid therapy has been shown to decrease the level of $\mathrm{CRP}^{[38]}$. PCT has been used to guide initiation and duration of antibiotic therapy without worse outcomes but has not been used to guide treatment with corticosteroids or other anti-inflammatory specific treatments ${ }^{[39-41]}$. Other less studied biomarkers are listed in Table 1.

\section{Cytokines in pneumonia}

Elevated pro-inflammatory cytokine (include IL-1, 6, and 8; TNF-alpha; and macrophage inflammatory protin-1beta) levels in CAP are indicative of a hyperinflammatory phenotype and are associated with increased disease severity, length of ICU and hospital stay, ventilator days, and mortality ${ }^{[7,42,43]}$. This phenotype may benefit from tailored treatments such as corticosteroids ${ }^{[17]}$. While cytokine panels may accurately identify the hyper-inflammatory phenotype, these panels are expensive, not universally available, and have a slow turn-around time that limits their ability to help guide potential treatments. Correlation of the natural history of CRP in relation to these cytokine patterns may allow for CRP to be a surrogate of these more expensive and cumbersome diagnostic panels.

\section{Biomarkers in ARDS}

Similar to CAP, biomarkers have the potential to aid in diagnosis, risk stratification, prognostication, and treatment response in ARDS. A wide variety of biomarkers have been studied in the ARDS population and many have been found to correlate with worse outcomes $^{[44]}$ (Table 2). A combination of biomarkers that pull from multiple areas described in conjunction with clinical predictors was found to be superior to any single component at mortality prediction ${ }^{[45]}$.

\section{Cytokines in ARDS}

Inflammatory cytokines have been extensively studied in ARDS and have proven useful at identifying hyper-inflammatory phenotypes. Utilizing latent class analysis and cytokine panels consisting of protein C, plasminogen activator inhibitor-1 (PAI-1), 
Table 2 Biomarkers in acute respiratory distress syndrome ${ }^{44}$

\begin{tabular}{lll}
\hline Pathways & Biomarkers & \\
\hline Epithelial & RAGE & \\
& SP-D & \\
& KL-6 & \\
& CC16 & \\
KGF & Ang-1/2 & \\
Endothelial & vWF & \\
& VEGF & IL-1 $\beta$ \\
Inflammatory & Pro-inflammatory & IL-6 \\
& & TNFa \\
& & IL-8 \\
& & IL-18 \\
& & ILRA \\
Coagulation and Fibrinolysis & & sTNF-RI/II \\
\hline & & IL-10 \\
\hline
\end{tabular}

RAGE: Receptor for advanced glycation end-product; SP-D: Serum surfactant protein D; KL-6: Kreb von den Lungen-6; CC16: Clara cell secretory protein; KGF: Keratinocyte growth factor; Ang 1/2: Barrier stabilizing angiopoietin 1/2; vWF: Von willebrand factor; VEGF: Vascular endothelial growth factor; IL: Interleukin; sTNF-RI/II: Soluble tissue necrosis factor receptor I/II; PAI-1: Plasminogen activator inhibitor-a.

IL-6 and 8, TNF receptor-I, intercellular adhesion molecule-1 (ICAM-1), surfactant protein D, and von Willebrand factor antigen, Calfee $e t$ al ${ }^{[8]}$ identified two ARDS phenotypes, a hyper and hypo-inflammatory type. The hyper-inflammatory phenotype was associated with increased inflammatory biomarker levels (IL-6 and 8, TNFr1, PAI-1, and ICAM-1) vasopressor use, prevalence of sepsis, acidosis, and 90-d mortality, and decreased ventilator and organ failure free days. Furthermore, a high PEEP strategy was associated with a significant decrease in mortality in the hyperinflammatory group suggesting a possible therapeutic implication of distinguishing phenotypes ${ }^{[8]}$. These two types persisted over time with $>94 \%$ of patients remaining within their initial phenotype by hospital day three ${ }^{[46]}$. A follow up study with 2 distinct cohorts demonstrated increased levels of markers of epithelial cell injury with decreased levels of markers of endothelial injury in direct ARDS (defined as those with pulmonary cause such as pneumonia) compared with indirect ARDS (caused by non-pulmonary etiologies such as sepsis) ${ }^{[47]}$. To stratify even further, inflammatory biomarkers have been shown to be elevated in mixed ICU patients but not in trauma patients ${ }^{[4-50]}$. More recently, a study utilizing logistic regression, evaluated 20 biomarkers including those in the inflammatory, coagulation, and endothelial activation categories and again identified a hyper and hypo-inflammatory phenotype with the hyper-inflammatory phenotype demonstrating higher ICU mortality. Furthermore, it was discovered that a mere 4 biomarkers (IL-6, interferon gamma, angiopoetin $1 / 2$ and PAI-1) could be used to identify the hyper-inflammatory phenotype (AUC 0.98) $)^{[51]}$.

\section{CRP and PCT in ARDS}

The combination of PCT and CRP have been shown to correlate with severity of disease in patients with ARDS however, this is not true for either biomarker independently, and even less so for CRP ${ }^{[52]}$. However, serial CRP levels have been shown to correlate with treatment response to corticosteroids ${ }^{[53]}$. In addition, and in agreement with previous studies that found higher levels of inflammatory biomarkers in indirect ARDS, PCT levels are significantly higher in ARDS patients with sepsis making it a useful tool in identification of this population ${ }^{[54]}$.

CURRENT EVIDENCE ON ADJUNCT ANTI-INFLAMMATORY THERAPIES 
Early antimicrobial therapy and lung protective ventilation are essential management strategies in pneumonia and ARDS. In addition early neuromuscular blockade has been associated with improved survival and decreased ventilator days in severe $\mathrm{ARDS}^{[55]}$. As antimicrobial therapy alone is insufficient to curb an exaggerated inflammatory response, several studies have evaluated the use of anti-inflammatory agents including corticosteroids in these conditions.

\section{Corticosteroids}

Corticosteroids have wide-ranging therapeutic application in the critically ill, particularly as anti-inflammatory agents for a variety of acute illnesses. Corticosteroids bind to glucocorticoid receptors intracellularly prompting genomic signaling with subsequent effects on gene transcription and post-translation ${ }^{[5]}$. These result in downstream inhibition and blockade of a variety of pro-inflammatory mediators including ILs, TNF nuclear factor- $\mathrm{kB}$, and suppression of inflammatory eicosanoids and cyclooxygenase 2 .

Insufficient suppression of nuclear factor-kB and increased levels of proinflammatory cytokines are thought to be a major driver of pulmonary inflammation in ARDS ${ }^{[77-59]}$ and severe CAP ${ }^{[60]}$ associated with worse outcomes ${ }^{[61]}$. Therefore the use of corticosteroids to blunt these effects has been proposed ${ }^{[62,63]}$. Translational efforts of these hypotheses however have been inconsistent in demonstrating clinical benefit.

\section{CAP}

Early studies and subsequent meta-analyses found improvements in mortality, ventilator-free days, time to clinical stabilization, and reduced lengths of stays ${ }^{[6-66]}$. The recent society of critical care medicine (SCCM)/ European society of intensive care medicine (ESICM) guidelines thus suggest the use of adjunctive corticosteroids in hospitalized patients with $\mathrm{CAP}^{[67]}$.

Unfortunately, these studies included heterogeneous populations and more importantly patients with CAP of wide-ranging severities. Nonetheless, there appeared to be early signal that patients with severe CAP may be those who benefit greatest from corticosteroids. A more contemporary meta-analysis of nine randomized controlled trials and six observational studies found no difference in survival, even in patients with severe $\mathrm{CAP}^{[68]}$. Interestingly, progression to ARDS was reduced in corticosteroid recipients. Furthermore, an individual patient data metaanalysis of six studies found corticosteroids reduced time to clinical stabilization and time in the hospital, but had no effects on survival, regardless of severity of the disease ${ }^{[69]}$. More recently, a meta-analysis of ten studies of severe CAP found corticosteroids were associated with improved in-hospital survival, but no clinical effect or differences in ventilator duration ${ }^{[70]}$.

The ESCAPe trial a multicenter, randomized controlled study in patients with severe CAP requiring ICU admission who met IDSA/ATS guideline criteria (NCT01283009) was recently concluded and results due to be published. Patients were randomized to methylprednisolone $40 \mathrm{mg}$ per day for $7 \mathrm{~d}$ followed by $20 \mathrm{mg}$ per $\mathrm{d}$ for $7 \mathrm{~d}$ followed by $12 \mathrm{mg}$ per day for $6 \mathrm{~d}$ followed by $4 \mathrm{mg}$ per day for $6 \mathrm{~d}$ or placebo with a primary outcome of 60 -d all-cause mortality.

Corticosteroid use in pathogen-specific CAPs has had somewhat more consistent findings. Studies of corticosteroids for CAP from influenza have rather consistently shown delayed viral clearance and increased mortality ${ }^{[71]}$. While corticosteroids provide considerable mortality benefit in CAP from Pneumocystis in HIV-positive individuals ${ }^{[72]}$, their benefit in other immune-suppressed hosts without HIV has not been substantiated ${ }^{[73]}$. Corticosteroid use in CAP from Aspergillus has shown increased mortality amongst hematopoietic cell transplant recipients ${ }^{[74,75]}$, whereas solid organ transplant recipients have reduced mortality ${ }^{[76]}$.

Because of their propensity to induce hyperglycemia, neuropsychiatric effects, immune-suppression and thereby potentially increased infection, suppressed wound healing, sodium retention, among other adverse effects ${ }^{[56]}$, judicious use of corticosteroids in the critically ill - a population already at high risk of poor outcome is becoming increasingly more important. Use of biomarkers may therefore inform steroid use, dosing and duration in patients with severe CAP and may potentially provide individualized selection of patients most likely to benefit. However, evaluation of contemporary clinical practice reveals corticosteroid use in CAP is not consistent with CRP and PCT concentrations ${ }^{[77]}$, and requires further investigation.

\section{ARDS}

A major contributor to the controversy of using corticosteroids for treatment of ARDS is the heterogeneity of studies published, wherein different dosing strategies are used, timing of initiation of steroids varies, outcomes studied are different, and the evolution of identifying and classifying the syndrome overtime. While a meta- 
analysis of nine studies found increase ventilator-free days but did not demonstrate survival benefit ${ }^{[78]}$, a subsequent individual patient data analysis and trial level metaanalysis showed prolonged corticosteroids increased both survival and ventilator-free days ${ }^{[79]}$. More recently, a study of hydrocortisone initiated within 12 hours of severe sepsis-associated ARDS found improved oxygenation but not time to liberation of the ventilator or survival ${ }^{[8]}$.

Timing of corticosteroid initiation may be an important consideration in ARDS. The ARDSNet trial randomized patients with ARDS that was persistent beyond $7 \mathrm{~d}$ and found improved oxygenation and ventilator compliance resulting in increased ventilator-free days, but again, no survival benefit ${ }^{[81]}$. More importantly, when corticosteroids were initiated late after ARDS onset (defined by $14 \mathrm{~d}$ ), they were associated with increased mortality. Other studies have had similar findings where greater survival and ventilator-free days were observed if corticosteroids were initiated within $72 \mathrm{~h}^{[53]}$. When concomitant pneumonia is present, initiation of corticosteroids within $12 \mathrm{~h}$ may result in more beneficial outcomes including reduced need for and duration on the ventilator and reduced hospital mortality ${ }^{[82]}$.

Based on this cumulative evidence, the recent SCCM/ESICM guidelines suggests the use of corticosteroid in patients with early moderate to severe ARDS within $14 \mathrm{~d}$ of onset ${ }^{[67]}$.

The DEXA-ARDS trial a multicenter, randomized controlled study in patients with moderate to severe ARDS persistent beyond $24 \mathrm{~h}$ was recently concluded and results due to be published ${ }^{[83]}$. Patients were randomized to dexamethasone $20 \mathrm{mg}$ per day for $5 \mathrm{~d}$ followed by $10 \mathrm{mg}$ per day for $5 \mathrm{~d}$ or placebo with ventilator-free days as primary outcome.

\section{OTHER ANTI-INFLAMMATORY THERAPIES}

Many different pharmacotherapies exerting anti-inflammatory actions have been mechanistically believed to provide benefits for pulmonary inflammation in ARDS and CAP. The majority of these therapies have failed to show clinical benefit, including statins ${ }^{[84]}$, neutrophil elastase inhibitors ${ }^{[5]}$, and ibuprofen ${ }^{[86]}$. An open-label study of moderate to severe ARDS found improved oxygenation at $48 \mathrm{~h}$ and reductions in inflammatory markers with use of inhaled sevoflurane ${ }^{[87]}$.

Anti-platelet agents have been proposed to suppress neutrophil-recruitment induced by platelet activation. Early observational studies found a signal of aspirin use prior to admission to the hospital reduced progression to ARDS ${ }^{[88,89]}$. In a randomized study, early administration of aspirin to patients at risk of ARDS did not reduce the risk of $\mathrm{ARDS}^{\left[{ }^{00]}\right.}$. There have been no investigations of aspirin for the treatment of those who have already developed ARDS.

Macrolide antimicrobials have been shown to suppress proinflammatory actions of nuclear factor-kB and inhibition of the nitric oxide pathway-driven inflammatory effects ${ }^{[91]}$. In an observational ARDS study, LARMA, a subset of patients who received macrolide antimicrobials as part of their clinical management had a signal towards improved long-term mortality ${ }^{[92]}$, though these benefits have not been substantiated in larger, controlled studies.

The PETAL network recently completed a study evaluating the effect of early vitamin D3 administration in patients at high risk of ARDS and is awaiting release of results (NCT03096314). A study evaluating the efficacy, safety, and effects on inflammatory biomarkers of inhaled carbon monoxide in ARDS will be recruiting soon (NCT03799874).

\section{FUTURE DIRECTIONS}

In the era of precision medicine, biomarkers have the potential to guide disease specific evaluation and management strategies in critically ill patients with CAP and ARDS with the goal of improvement in outcomes of both conditions and early ARDS prevention. The ideal biomarker should be accurate, reproducible ${ }^{[22]}$, detected early ${ }^{[44]}$, clearly reflect the degree of inflammation, response to treatment ${ }^{[25]}$ and trajectory of illness, and identify patients at risk of worse outcomes ${ }^{[03]}$. Furthermore, an ideal biomarker in pneumonia and ARDS should be inexpensive, easily available, rapidly analyzable and consistent across all groups of patients for generalizability to be useful in clinical practice.

Pragmatic clinical trials with an adaptive design are needed to further define the roles of inflammatory biomarkers (individually or as a panel) as predictive and/or prognostic enrichment tools as well as therapeutic guides in acute pulmonary 
inflammation in critically ill patients.

\section{CONCLUSION}

In addition to early antibiotics, safe lung ventilation strategies and neuromuscular blockade, corticosteroids are the only anti-inflammatory medications with potential benefits in these conditions. Inflammatory biomarkers have been used for early diagnosis, assessment of severity, and prognostication in CAP and ARDS. The use of biomarkers for patient selection and for guiding adjunct anti-inflammatory treatment is appealing however, further studies are needed to define their role in clinical practice.

\section{REFERENCES}

Moldoveanu B, Otmishi P, Jani P, Walker J, Sarmiento X, Guardiola J, Saad M, Yu J. Inflammatory mechanisms in the lung. J Inflamm Res 2009; 2: 1-11 [PMID: 22096348 DOI: 10.2147/JIR.S4385]

2 Ramirez JA, Wiemken TL, Peyrani P, Arnold FW, Kelley R, Mattingly WA, Nakamatsu R, Pena S, Guinn BE, Furmanek SP, Persaud AK, Raghuram A, Fernandez F, Beavin L, Bosson R, Fernandez-Botran R, Cavallazzi R, Bordon J, Valdivieso C, Schulte J, Carrico RM; University of Louisville Pneumonia Study Group. Adults Hospitalized With Pneumonia in the United States: Incidence, Epidemiology, and Mortality. Clin Infect Dis 2017; 65: 1806-1812 [PMID: 29020164 DOI: 10.1093/cid/cix647]

3 Kochanek KD, Murphy SL, Xu J, Tejada-Vera B. Deaths: Final Data for 2014. Natl Vital Stat Rep 2016; 65: 1-122 [PMID: 27378572]

4 Storms AD, Chen J, Jackson LA, Nordin JD, Naleway AL, Glanz JM, Jacobsen SJ, Weintraub ES, Klein NP, Gargiullo PM, Fry AM. Rates and risk factors associated with hospitalization for pneumonia with ICU admission among adults. BMC Pulm Med 2017; 17: 208 [PMID: 29246210 DOI: 10.1186/s12890-017-0552-x]

5 Bellani G, Laffey JG, Pham T, Fan E; LUNG SAFE Investigators and the ESICM Trials Group. The LUNG SAFE study: a presentation of the prevalence of ARDS according to the Berlin Definition! Crit Care 2016; 20: 268 [PMID: 27608629 DOI: 10.1186/s13054-016-1443-x]

6 Restrepo MI, Mortensen EM, Velez JA, Frei C, Anzueto A. A comparative study of community-acquired pneumonia patients admitted to the ward and the ICU. Chest 2008; 133: 610-617 [PMID: 17989157 DOI: 10.1378/chest.07-1456]

7 Martínez R, Menéndez R, Reyes S, Polverino E, Cillóniz C, Martínez A, Esquinas C, Filella X, Ramírez $\mathrm{P}$, Torres A. Factors associated with inflammatory cytokine patterns in community-acquired pneumonia. Eur Respir J 2011; 37: 393-399 [PMID: 20595152 DOI: 10.1183/09031936.00040710]

8 Calfee CS, Delucchi K, Parsons PE, Thompson BT, Ware LB, Matthay MA; NHLBI ARDS Network. Subphenotypes in acute respiratory distress syndrome: latent class analysis of data from two randomised controlled trials. Lancet Respir Med 2014; 2: 611-620 [PMID: 24853585 DOI: 10.1016/S2213-2600(14)70097-9]

9 Adler KB, Fischer BM, Wright DT, Cohn LA, Becker S. Interactions between respiratory epithelial cells and cytokines: relationships to lung inflammation. Ann N Y Acad Sci 1994; 725: 128-145 [PMID: 8030984 DOI: $10.1111 / j .1749-6632.1994 . t b 00275 . x]$

10 Kaisho T, Akira S. Toll-like receptor function and signaling. J Allergy Clin Immunol 2006; 117: 979-87; quiz 988 [PMID: 16675322 DOI: 10.1016/j.jaci.2006.02.023]

11 Toossi Z, Hirsch CS, Hamilton BD, Knuth CK, Friedlander MA, Rich EA. Decreased production of TGFbeta 1 by human alveolar macrophages compared with blood monocytes. J Immunol 1996; 156: 3461-3468 [PMID: 8617974]

12 Pierrakos C, Karanikolas M, Scolletta S, Karamouzos V, Velissaris D. Acute respiratory distress syndrome: pathophysiology and therapeutic options. J Clin Med Res 2012; 4: 7-16 [PMID: 22383921 DOI: $10.4021 /$ jocmr $761 \mathrm{w}]$

13 Windsor AC, Mullen PG, Fowler AA, Sugerman HJ. Role of the neutrophil in adult respiratory distress syndrome. Br J Surg 1993; 80: 10-17 [PMID: 8428262 DOI: 10.1002/bjs.1800800106]

14 Gadek JE, Pacht ER. The interdependence of lung antioxidants and antiprotease defense in ARDS. Chest 1996; 110: 273S-277S [PMID: 8989164 DOI: 10.1378/chest.110.6_Supplement.273S]

15 Moine P, McIntyre R, Schwartz MD, Kaneko D, Shenkar R, Le Tulzo Y, Moore EE, Abraham E. NFkappaB regulatory mechanisms in alveolar macrophages from patients with acute respiratory distress syndrome. Shock 2000; 13: 85-91 [PMID: 10670837 DOI: 10.1097/00024382-200013020-00001]

16 Amur S. Biomarker Terminology: Speaking The Same Language [Internet]. 2019. Available from: https://www.fda.gov/downloads/Drugs/DevelopmentApprovalProcess/DrugDevelopmentToolsQualificationProgram/UCM533161.pdf

17 Torres A, Sibila O, Ferrer M, Polverino E, Menendez R, Mensa J, Gabarrús A, Sellarés J, Restrepo MI, Anzueto A, Niederman MS, Agustí C. Effect of corticosteroids on treatment failure among hospitalized patients with severe community-acquired pneumonia and high inflammatory response: a randomized clinical trial. JAMA 2015; 313: 677-686 [PMID: 25688779 DOI: 10.1001/jama.2015.88]

18 Tillett WS, Francis T. SEROLOGICAL REACTIONS IN PNEUMONIA WITH A NON-PROTEIN SOMATIC FRACTION OF PNEUMOCOCCUS. J Exp Med 1930; 52: 561-571 [PMID: 19869788 DOI: 10.1084/jem.52.4.561]

19 Male D, Brostoff J, Roth D. Chapter 6: Mechanisms of Innate Injury. In: Immunology. 8th ed. Elsevier 2013;

20 Chernecky CC, Berger BJ. Laboratory Tests and Diagnostic Procedures. In: Laboratory tests and diagnostic procedures. 6th ed. St. Louis, MO: Elsevier Saunders; 2013;

21 Ballou SP, Kushner I. C-reactive protein and the acute phase response. Adv Intern Med 1992; 37: 313-336 [PMID: 1558000]

22 Sibila $\mathbf{O}$, Restrepo MI. Biomarkers in community-acquired pneumonia: still searching for the one. Eur 
Respir J 2019; 53 [PMID: 30819808 DOI: 10.1183/13993003.02469-2018]

23 Jin M, Khan AI. Procalcitonin: Uses in the Clinical Laboratory for the Diagnosis of Sepsis. Lab Med 2010; 41: 173-177 [DOI: 10.1309/LMQ2GRR4QLFKHCH9]

24 Gilbert DN. Use of plasma procalcitonin levels as an adjunct to clinical microbiology. J Clin Microbiol 2010; 48: 2325-2329 [PMID: 20421436 DOI: 10.1128/JCM.00655-10]

25 Shaddock EJ. How and when to use common biomarkers in community-acquired pneumonia. Pneumonia (Nathan) 2016; 8: 17 [PMID: 28702296 DOI: 10.1186/s41479-016-0017-7]

26 Amour J, Birenbaum A, Langeron O, Le Manach Y, Bertrand M, Coriat P, Riou B, Bernard M, Hausfater P. Influence of renal dysfunction on the accuracy of procalcitonin for the diagnosis of postoperative infection after vascular surgery. Crit Care Med 2008; 36: 1147-1154 [PMID: 18379240 DOI: 10.1097/CCM.0b013e3181692966]

27 Müller B, Harbarth S, Stolz D, Bingisser R, Mueller C, Leuppi J, Nusbaumer C, Tamm M, Christ-Crain $\mathrm{M}$. Diagnostic and prognostic accuracy of clinical and laboratory parameters in community-acquired pneumonia. BMC Infect Dis 2007; 7: 10 [PMID: 17335562 DOI: 10.1186/1471-2334-7-10]

28 Méndez R, Menéndez R, Cillóniz C, Amara-Elori I, Amaro R, González P, Posadas T, Gimeno A, España $\mathrm{PP}$, Almirall J, Torres A. Initial Inflammatory Profile in Community-acquired Pneumonia Depends on Time since Onset of Symptoms. Am J Respir Crit Care Med 2018; 198: 370-378 [PMID: 29509439 DOI: 10.1164/rccm.201709-1908OC]

29 Keramat F, Ghasemi Basir HR, Abdoli E, Shafiei Aghdam A, Poorolajal J. Association of serum procalcitonin and C-reactive protein levels with CURB-65 criteria among patients with communityacquired pneumonia. Int J Gen Med 2018; 11: 217-223 [PMID: 29942144 DOI: 10.2147/IJGM.S165190]

30 Krüger S, Ewig S, Marre R, Papassotiriou J, Richter K, von Baum H, Suttorp N, Welte T; CAPNETZ Study Group. Procalcitonin predicts patients at low risk of death from community-acquired pneumonia across all CRB-65 classes. Eur Respir J 2008; 31: 349-355 [PMID: 17959641 DOI: 10.1183/09031936.00054507]

31 Schuetz P, Suter-Widmer I, Chaudri A, Christ-Crain M, Zimmerli W, Mueller B; Procalcitonin-Guided Antibiotic Therapy and Hospitalisation in Patients with Lower Respiratory Tract Infections (ProHOSP) Study Group. Prognostic value of procalcitonin in community-acquired pneumonia. Eur Respir J 2011; 37: 384-392 [PMID: 20595156 DOI: 10.1183/09031936.00035610]

32 Guo S, Mao X, Liang M. The moderate predictive value of serial serum CRP and PCT levels for the prognosis of hospitalized community-acquired pneumonia. Respir Res 2018; 19: 193 [PMID: 30285748 DOI: 10.1186/s12931-018-0877-x]

33 Ito A, Ishida $\mathrm{T}$, Tachibana $\mathrm{H}$, Ito $\mathrm{Y}$, Takaiwa $\mathrm{T}$. Serial procalcitonin levels for predicting prognosis in community-acquired pneumonia. Respirology 2016; 21: 1459-1464 [PMID: 27398948 DOI: 10.1111/resp.12846]

34 Farah R, Khamisy-Farah R, Makhoul N. Consecutive Measures of CRP Correlate with Length of Hospital Stay in Patients with Community-Acquired Pneumonia. Isr Med Assoc J 2018; 20: 345-348 [PMID: 29911753]

35 Andersen SB, Baunbæk Egelund G, Jensen AV, Petersen PT, Rohde G, Ravn P. Failure of CRP decline within three days of hospitalization is associated with poor prognosis of Community-acquired Pneumonia. Infect Dis (Lond) 2017; 49: 251-260 [PMID: 27887037 DOI: 10.1080/23744235.2016.1253860]

36 Kim MW, Lim JY, Oh SH. Mortality prediction using serum biomarkers and various clinical risk scales in community-acquired pneumonia. Scand J Clin Lab Invest 2017; 77: 486-492 [PMID: 28678546 DOI: 10.1080/00365513.2017.1344298]

37 Wang X, Jiao J, Wei R, Feng Y, Ma X, Li Y, Du Y. A new method to predict hospital mortality in severe community acquired pneumonia. Eur J Intern Med 2017; 40: $56-63$ [PMID: 28320569 DOI: 10.1016/j.ejim.2017.02.013]

38 Fernández-Serrano S, Dorca J, Garcia-Vidal C, Fernández-Sabé N, Carratalà J, Fernández-Agüera A, Corominas M, Padrones S, Gudiol F, Manresa F. Effect of corticosteroids on the clinical course of community-acquired pneumonia: a randomized controlled trial. Crit Care 2011; 15: R96 [PMID: 21406101 DOI: $10.1186 / \mathrm{cc} 10103]$

39 Christ-Crain M, Jaccard-Stolz D, Bingisser R, Gencay MM, Huber PR, Tamm M, Müller B. Effect of procalcitonin-guided treatment on antibiotic use and outcome in lower respiratory tract infections: clusterrandomised, single-blinded intervention trial. Lancet 2004; 363: 600-607 [PMID: 14987884 DOI: 10.1016/S0140-6736(04)15591-8]

40 Christ-Crain M, Stolz D, Bingisser R, Müller C, Miedinger D, Huber PR, Zimmerli W, Harbarth S, Tamm M, Müller B. Procalcitonin guidance of antibiotic therapy in community-acquired pneumonia: a randomized trial. Am J Respir Crit Care Med 2006; 174: 84-93 [PMID: 16603606 DOI: 10.1164/rccm.200512-19220C]

41 Schuetz P, Christ-Crain M, Thomann R, Falconnier C, Wolbers M, Widmer I, Neidert S, Fricker T, Blum C, Schild U, Regez K, Schoenenberger R, Henzen C, Bregenzer T, Hoess C, Krause M, Bucher HC, Zimmerli W, Mueller B; ProHOSP Study Group. Effect of procalcitonin-based guidelines vs standard guidelines on antibiotic use in lower respiratory tract infections: the ProHOSP randomized controlled trial. JAMA 2009; 302: 1059-1066 [PMID: 19738090 DOI: 10.1001/jama.2009.1297]

42 Fernández-Serrano S, Dorca J, Coromines M, Carratalà J, Gudiol F, Manresa F. Molecular inflammatory responses measured in blood of patients with severe community-acquired pneumonia. Clin Diagn Lab Immunol 2003; 10: 813-820 [PMID: 12965910 DOI: 10.1128/CDLI.10.5.813-820.2003]

43 Ramírez P, Ferrer M, Martí V, Reyes S, Martínez R, Menéndez R, Ewig S, Torres A. Inflammatory biomarkers and prediction for intensive care unit admission in severe community-acquired pneumonia. Crit Care Med 2011; 39: 2211-2217 [PMID: 21705887 DOI: 10.1097/CCM.0b013e3182257445]

44 Spadaro S, Park M, Turrini C, Tunstall T, Thwaites R, Mauri T, Ragazzi R, Ruggeri P, Hansel TT, Caramori G, Volta CA. Biomarkers for Acute Respiratory Distress syndrome and prospects for personalised medicine. J Inflamm (Lond) 2019; 16: 1 [PMID: 30675131 DOI: 10.1186/s12950-018-0202-y]

45 Ware LB, Koyama T, Billheimer DD, Wu W, Bernard GR, Thompson BT, Brower RG, Standiford TJ, Martin TR, Matthay MA; NHLBI ARDS Clinical Trials Network. Prognostic and pathogenetic value of combining clinical and biochemical indices in patients with acute lung injury. Chest 2010; 137: 288-296 [PMID: 19858233 DOI: 10.1378/chest.09-1484]

46 Delucchi K, Famous KR, Ware LB, Parsons PE, Thompson BT, Calfee CS; ARDS Network. Stability of ARDS subphenotypes over time in two randomised controlled trials. Thorax 2018; 73: 439-445 [PMID: 29477989 DOI: 10.1136/thoraxjnl-2017-211090] 
47 Calfee CS, Janz DR, Bernard GR, May AK, Kangelaris KN, Matthay MA, Ware LB. Distinct molecular phenotypes of direct vs indirect ARDS in single-center and multicenter studies. Chest 2015; 147: 15391548 [PMID: 26033126 DOI: 10.1378/chest.14-2454]

48 Meade P, Shoemaker WC, Donnelly TJ, Abraham E, Jagels MA, Cryer HG, Hugli TE, Bishop MH, Wo CC. Temporal patterns of hemodynamics, oxygen transport, cytokine activity, and complement activity in the development of adult respiratory distress syndrome after severe injury. J Trauma 1994; 36: 651-657 [PMID: 8189465 DOI: 10.1097/00005373-199405000-00009]

49 Cepkova M, Brady S, Sapru A, Matthay MA, Church G. Biological markers of lung injury before and after the institution of positive pressure ventilation in patients with acute lung injury. Crit Care 2006; 10: R126 [PMID: 16956410 DOI: 10.1186/cc5037]

50 Nakamura T, Sato E, Fujiwara N, Kawagoe Y, Maeda S, Yamagishi S. Increased levels of soluble receptor for advanced glycation end products (sRAGE) and high mobility group box 1 (HMGB1) are associated with death in patients with acute respiratory distress syndrome. Clin Biochem 2011; 44: 601-604 [PMID: 21211520 DOI: 10.1016/j.clinbiochem.2010.12.014]

51 Bos LD, Schouten LR, van Vught LA, Wiewel MA, Ong DSY, Cremer O, Artigas A, Martin-Loeches I, Hoogendijk AJ, van der Poll T, Horn J, Juffermans N, Calfee CS, Schultz MJ; MARS consortium. Identification and validation of distinct biological phenotypes in patients with acute respiratory distress syndrome by cluster analysis. Thorax 2017; 72: 876-883 [PMID: 28450529 DOI: 10.1136/thoraxjnl-2016-209719]

$52 \mathbf{Y u ~ Z , ~ J i ~ M , ~ H u ~ X , ~ Y a n ~ J , ~ J i n ~ Z . ~ [ V a l u e ~ o f ~ p r o c a l c i t o n i n ~ o n ~ p r e d i c t i n g ~ t h e ~ s e v e r i t y ~ a n d ~ p r o g n o s i s ~ i n ~}$ patients with early ARDS: a prospective observation study]. Zhonghua Wei Zhong Bing Ji Jiu Yi Xue 2017; 29: 34-38 [PMID: 28459401 DOI: 10.3760/cma.j.issn.2095-4352.2017.01.008]

53 Meduri GU, Golden E, Freire AX, Taylor E, Zaman M, Carson SJ, Gibson M, Umberger R. Methylprednisolone infusion in early severe ARDS: results of a randomized controlled trial. Chest 2007; 131: 954-963 [PMID: 17426195 DOI: 10.1378/chest.06-2100]

54 Brunkhorst FM, Eberhard OK, Brunkhorst R. Discrimination of infectious and noninfectious causes of early acute respiratory distress syndrome by procalcitonin. Crit Care Med 1999; 27: 2172-2176 [PMID: 10548201 DOI: 10.1097/00003246-199910000-00016]

55 Papazian L, Forel JM, Gacouin A, Penot-Ragon C, Perrin G, Loundou A, Jaber S, Arnal JM, Perez D, Seghboyan JM, Constantin JM, Courant P, Lefrant JY, Guérin C, Prat G, Morange S, Roch A; ACURASYS Study Investigators. Neuromuscular blockers in early acute respiratory distress syndrome. $N$ Engl J Med 2010; 363: 1107-1116 [PMID: 20843245 DOI: 10.1056/NEJMoa1005372]

56 Rhen T, Cidlowski JA. Antiinflammatory action of glucocorticoids--new mechanisms for old drugs. $N$ Engl J Med 2005; 353: 1711-1723 [PMID: 16236742 DOI: 10.1056/NEJMra050541]

57 Franchimont D, Kino T, Galon J, Meduri GU, Chrousos G. Glucocorticoids and inflammation revisited: the state of the art. NIH clinical staff conference. Neuroimmunomodulation 2002; 10: 247-260 [PMID: 12759562 DOI: 10.1159/000069969]

58 Meduri GU, Annane D, Chrousos GP, Marik PE, Sinclair SE. Activation and regulation of systemic inflammation in ARDS: rationale for prolonged glucocorticoid therapy. Chest 2009; 136: 1631-1643 [PMID: 19801579 DOI: 10.1378/chest.08-2408]

59 Thompson BT, Chambers RC, Liu KD. Acute Respiratory Distress Syndrome. N Engl J Med 2017; 377 : 562-572 [PMID: 28792873 DOI: 10.1056/NEJMra1608077]

60 Puren AJ, Feldman C, Savage N, Becker PJ, Smith C. Patterns of cytokine expression in communityacquired pneumonia. Chest 1995; 107: 1342-1349 [PMID: 7750329 DOI: 10.1378/chest.107.5.1342]

61 Meduri GU, Headley S, Kohler G, Stentz F, Tolley E, Umberger R, Leeper K. Persistent elevation of inflammatory cytokines predicts a poor outcome in ARDS. Plasma IL-1 beta and IL-6 levels are consistent and efficient predictors of outcome over time. Chest 1995; 107: 1062-1073 [PMID: 7705118 DOI: 10.1378/chest.107.4.1062]

62 Meduri GU, Marik PE, Chrousos GP, Pastores SM, Arlt W, Beishuizen A, Bokhari F, Zaloga G, Annane D. Steroid treatment in ARDS: a critical appraisal of the ARDS network trial and the recent literature. Intensive Care Med 2008; 34: 61-69 [PMID: 18000649 DOI: 10.1007/s00134-007-0933-3]

63 Confalonieri M, Urbino R, Potena A, Piattella M, Parigi P, Puccio G, Della Porta R, Giorgio C, Blasi F, Umberger R, Meduri GU. Hydrocortisone infusion for severe community-acquired pneumonia: a preliminary randomized study. Am J Respir Crit Care Med 2005; 171: 242-248 [PMID: 15557131 DOI: 10.1164/rccm.200406-8080C]

64 Siemieniuk RA, Meade MO, Alonso-Coello P, Briel M, Evaniew N, Prasad M, Alexander PE, Fei Y, Vandvik PO, Loeb M, Guyatt GH. Corticosteroid Therapy for Patients Hospitalized With CommunityAcquired Pneumonia: A Systematic Review and Meta-analysis. Ann Intern Med 2015; 163: 519-528 [PMID: 26258555 DOI: 10.7326/M15-0715]

65 Horita N, Otsuka T, Haranaga S, Namkoong H, Miki M, Miyashita N, Higa F, Takahashi H, Yoshida M, Kohno S, Kaneko T. Adjunctive Systemic Corticosteroids for Hospitalized Community-Acquired Pneumonia: Systematic Review and Meta-Analysis 2015 Update. Sci Rep 2015; 5: 14061 [PMID: 26374694 DOI: $10.1038 /$ srep 14061]

66 Marti C, Grosgurin O, Harbarth S, Combescure C, Abbas M, Rutschmann O, Perrier A, Garin N. Adjunctive Corticotherapy for Community Acquired Pneumonia: A Systematic Review and MetaAnalysis. PLoS One 2015; 10: e0144032 [PMID: 26641253 DOI: 10.1371/journal.pone.0144032]

67 Pastores SM, Annane D, Rochwerg B, Corticosteroid Guideline Task Force of SCCM and ESICM. Guidelines for the Diagnosis and Management of Critical Illness-Related Corticosteroid Insufficiency (CIRCI) in Critically Ill Patients (Part II): Society of Critical Care Medicine (SCCM) and European Society of Intensive Care Medicine (ESICM) 2017. Crit Care Med 2018; 46: 146-148 [PMID: 29095205 DOI: 10.1097/CCM.0000000000002840]

68 Wan YD, Sun TW, Liu ZQ, Zhang SG, Wang LX, Kan QC. Efficacy and Safety of Corticosteroids for Community-Acquired Pneumonia: A Systematic Review and Meta-Analysis. Chest 2016; 149: 209-219 [PMID: 26501852 DOI: 10.1378/chest.15-1733]

69 Briel M, Spoorenberg SMC, Snijders D, Torres A, Fernandez-Serrano S, Meduri GU, Gabarrús A, Blum CA, Confalonieri M, Kasenda B, Siemieniuk RAC, Boersma W, Bos WJW, Christ-Crain M; Ovidius Study Group; Capisce Study Group; STEP Study Group. Corticosteroids in Patients Hospitalized With Community-Acquired Pneumonia: Systematic Review and Individual Patient Data Metaanalysis. Clin Infect Dis 2018; 66: 346-354 [PMID: 29020323 DOI: 10.1093/cid/cix801]

70 Wu WF, Fang Q, He GJ. Efficacy of corticosteroid treatment for severe community-acquired pneumonia: A meta-analysis. Am J Emerg Med 2018; 36: 179-184 [PMID: 28756034 DOI: 


\subsection{6/j.ajem.2017.07.050]}

71 Wieruszewski PM, Linn DD. Contemporary management of severe influenza disease in the intensive care unit. J Crit Care 2018; 48: 48-55 [PMID: 30172033 DOI: 10.1016/j.jcrc.2018.08.015]

72 National Institutes of Health-University of California Expert Panel for Corticosteroids as Adjunctive Therapy for Pneumocystis Pneumonia. Consensus statement on the use of corticosteroids as adjunctive therapy for pneumocystis pneumonia in the acquired immunodeficiency syndrome. N Engl J Med 1990; 323: 1500-1504 [PMID: 2136587 DOI: 10.1056/NEJM199011223232131]

73 Wieruszewski PM, Barreto JN, Frazee E, Daniels CE, Tosh PK, Dierkhising RA, Mara KC, Limper AH. Early Corticosteroids for Pneumocystis Pneumonia in Adults Without HIV Are Not Associated With Better Outcome. Chest 2018; 154: 636-644 [PMID: 29705221 DOI: 10.1016/j.chest.2018.04.026]

74 Nivoix Y, Velten M, Letscher-Bru V, Moghaddam A, Natarajan-Amé S, Fohrer C, Lioure B, Bilger K, Lutun P, Marcellin L, Launoy A, Freys G, Bergerat JP, Herbrecht R. Factors associated with overall and attributable mortality in invasive aspergillosis. Clin Infect Dis 2008; 47: 1176-1184 [PMID: 18808352 DOI: $10.1086 / 592255]$

75 Upton A, Kirby KA, Carpenter P, Boeckh M, Marr KA. Invasive aspergillosis following hematopoietic cell transplantation: outcomes and prognostic factors associated with mortality. Clin Infect Dis 2007; 44: 531-540 [PMID: 17243056 DOI: 10.1086/510592]

76 Baddley JW, Andes DR, Marr KA, Kontoyiannis DP, Alexander BD, Kauffman CA, Oster RA, Anaissie EJ, Walsh TJ, Schuster MG, Wingard JR, Patterson TF, Ito JI, Williams OD, Chiller T, Pappas PG. Factors associated with mortality in transplant patients with invasive aspergillosis. Clin Infect Dis 2010; 50: 15591567 [PMID: 20450350 DOI: 10.1086/652768]

77 Odeyemi Y, Herasevich S, Schwegman A, Barreto E, Gajic O, Yadav H. Biomarker concordant steroid use in critically ill patients with pneumonia. Crit Care Med 2019; 47: 521 [DOI: 10.1097/01.ccm.0000551834.00753.8a]

78 Peter JV, John P, Graham PL, Moran JL, George IA, Bersten A. Corticosteroids in the prevention and treatment of acute respiratory distress syndrome (ARDS) in adults: meta-analysis. BMJ 2008; 336: 10061009 [PMID: 18434379 DOI: $10.1136 / \mathrm{bmj} .39537 .939039 . \mathrm{BE}]$

79 Meduri GU, Bridges L, Shih MC, Marik PE, Siemieniuk RAC, Kocak M. Prolonged glucocorticoid treatment is associated with improved ARDS outcomes: analysis of individual patients' data from four randomized trials and trial-level meta-analysis of the updated literature. Intensive Care Med 2016; 42: 829840 [PMID: 26508525 DOI: 10.1007/s00134-015-4095-4]

80 Tongyoo S, Permpikul C, Mongkolpun W, Vattanavanit V, Udompanturak S, Kocak M, Meduri GU. Hydrocortisone treatment in early sepsis-associated acute respiratory distress syndrome: results of a randomized controlled trial. Crit Care 2016; 20: 329 [PMID: 27741949 DOI: 10.1186/s13054-016-1511-2]

81 Steinberg KP, Hudson LD, Goodman RB, Hough CL, Lanken PN, Hyzy R, Thompson BT, Ancukiewicz M; National Heart, Lung, and Blood Institute Acute Respiratory Distress Syndrome (ARDS) Clinical Trials Network. Efficacy and safety of corticosteroids for persistent acute respiratory distress syndrome. $N$ Engl J Med 2006; 354: 1671-1684 [PMID: 16625008 DOI: 10.1056/NEJMoa051693]

82 Herasevich S, Odeyemi Y, Wieruszewski P, Gajic O, Yadav H. Timeliness of corticosteroid use in ICU patients with pneumonia and ARDS. Crit Care Med 2019; 47: 557 [DOI: 10.1097/01.ccm.0000551906.96335.48]

83 Villar J, Belda J, Añón JM, Blanco J, Pérez-Méndez L, Ferrando C, Martínez D, Soler JA, Ambrós A, Muñoz T, Rivas R, Corpas R, Díaz-Dominguez FJ, Soro M, García-Bello MA, Fernández RL, Kacmarek RM; DEXA-ARDS Network. Evaluating the efficacy of dexamethasone in the treatment of patients with persistent acute respiratory distress syndrome: study protocol for a randomized controlled trial. Trials 2016; 17: 342 [PMID: 27449641 DOI: 10.1186/s13063-016-1456-4]

84 National Heart, Lung, and Blood Institute ARDS Clinical Trials Network. Truwit JD, Bernard GR, Steingrub J, Matthay MA, Liu KD, Albertson TE, Brower RG, Shanholtz C, Rock P, Douglas IS, deBoisblanc BP, Hough CL, Hite RD, Thompson BT. Rosuvastatin for sepsis-associated acute respiratory distress syndrome. $N$ Engl J Med 2014; 370: 2191-2200 [PMID: 24835849 DOI: 10.1056/NEJMoa1401520]

85 Iwata K, Doi A, Ohji G, Oka H, Oba Y, Takimoto K, Igarashi W, Gremillion DH, Shimada T. Effect of neutrophil elastase inhibitor (sivelestat sodium) in the treatment of acute lung injury (ALI) and acute respiratory distress syndrome (ARDS): a systematic review and meta-analysis. Intern Med 2010; 49: 24232432 [PMID: 21088343 DOI: 10.2169/internalmedicine.49.4010]

86 Bernard GR, Wheeler AP, Russell JA, Schein R, Summer WR, Steinberg KP, Fulkerson WJ, Wright PE, Christman BW, Dupont WD, Higgins SB, Swindell BB. The effects of ibuprofen on the physiology and survival of patients with sepsis. The Ibuprofen in Sepsis Study Group. N Engl J Med 1997; 336: $912-918$ [PMID: 9070471 DOI: 10.1056/NEJM199703273361303]

87 Jabaudon M, Boucher P, Imhoff E, Chabanne R, Faure JS, Roszyk L, Thibault S, Blondonnet R, Clairefond G, Guérin R, Perbet S, Cayot S, Godet T, Pereira B, Sapin V, Bazin JE, Futier E, Constantin JM. Sevoflurane for Sedation in Acute Respiratory Distress Syndrome. A Randomized Controlled Pilot Study. Am J Respir Crit Care Med 2017; 195: 792-800 [PMID: 27611637 DOI: 10.1164/rccm.201604-06860C]

88 Chen W, Janz DR, Bastarache JA, May AK, O'Neal HR, Bernard GR, Ware LB. Prehospital aspirin use is associated with reduced risk of acute respiratory distress syndrome in critically ill patients: a propensityadjusted analysis. Crit Care Med 2015; 43: 801-807 [PMID: 25559436 DOI: 10.1097/CCM.0000000000000789]

89 Erlich JM, Talmor DS, Cartin-Ceba R, Gajic O, Kor DJ. Prehospitalization antiplatelet therapy is associated with a reduced incidence of acute lung injury: a population-based cohort study. Chest 2011; 139: 289-295 [PMID: 20688925 DOI: 10.1378/chest.10-0891]

90 Kor DJ, Carter RE, Park PK, Festic E, Banner-Goodspeed VM, Hinds R, Talmor D, Gajic O, Ware LB, Gong MN; US Critical Illness and Injury Trials Group: Lung Injury Prevention with Aspirin Study Group (USCIITG: LIPS-A). Effect of Aspirin on Development of ARDS in At-Risk Patients Presenting to the Emergency Department: The LIPS-A Randomized Clinical Trial. JAMA 2016; 315: 2406-2414 [PMID: 27179988 DOI: 10.1001/jama.2016.6330]

91 Emmet O'Brien M, Restrepo MI, Martin-Loeches I. Update on the combination effect of macrolide antibiotics in community-acquired pneumonia. Respir Investig 2015; 53: 201-209 [PMID: 26344609 DOI: 10.1016/j.resinv.2015.05.003]

92 Walkey AJ, Wiener RS. Macrolide antibiotics and survival in patients with acute lung injury. Chest 2012; 
141: 1153-1159 [PMID: 22116799 DOI: 10.1378/chest.11-1908]

93 Krüger S, Welte T. Biomarkers in community-acquired pneumonia. Expert Rev Respir Med 2012; 6: 203214 [PMID: 22455492 DOI: 10.1586/ers.12.6] 


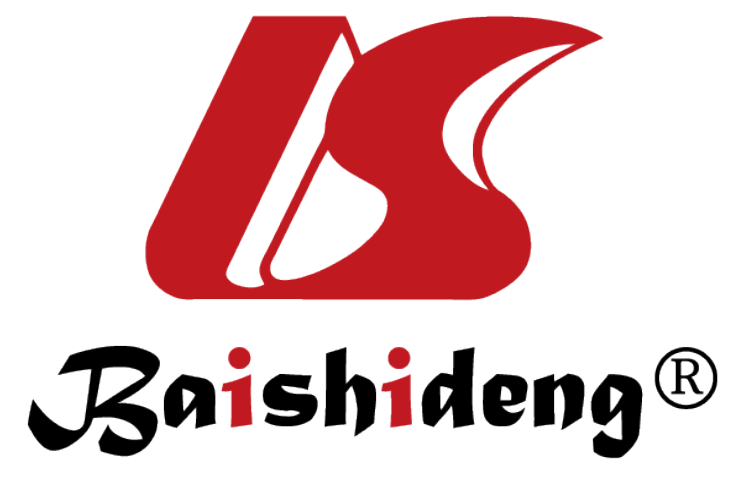

Published By Baishideng Publishing Group Inc

7041 Koll Center Parkway, Suite 160, Pleasanton, CA 94566, USA

Telephone: +1-925-2238242

Fax: +1-925-2238243

E-mail: bpgoffice@wjgnet.com

Help Desk: https://www.f6publishing.com/helpdesk

https://www.wjgnet.com

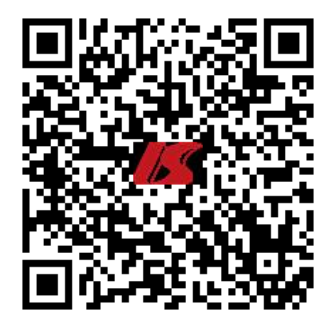

